\section{JHRM 10,3}

\section{4}

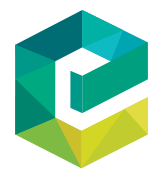

Journal of Historical Research in Marketing Vol. 10 No. 3, 2018 pp. 194-196 (c) Emerald Publishing Limited 1755-750X DOI 10.1108/JHRM-08-2018-079

\section{Editorial}

\section{Multiple histories of marketing in India}

Like any large and complex nation, India has multiple histories. These histories continue to cast their shadows over contemporary India's economic, political and cultural institutions and activities. Some of India's histories span millennia, others span centuries, and yet others are just decades old. Some "histories" of India are actually mythologies that continue to exert sociopolitical force on current events.

Over millennia, the territorial geographies of India - to be accurate, of the concept or idea called "India" - have waxed and waned, depending on the fortunes of the rulers and their military strategies. Because at some point in history, under a certain monarch, an Indian empire stretched from the present-day Afghanistan to the present-day Myanmar or Burma; some ultra-nationalists in contemporary India bemoan the loss of such geo-greatness - especially following the 1947 partition that ultimately created three nations (India, Pakistan and Bangladesh) out of one political entity under British colonial rule.

Over centuries, and especially at the zenith of the Mughal empire in India under Emperor Akbar, in the late sixteenth century, India's economy became large and a significant contributor to global trade. There are some scholarly disagreements on when the great divergence between Western Europe and India began. On the one hand, several accounts by scholars such as Bagchi (1976), Frank (1998) and Pomeranz (2000) attribute India's decline to colonialism. On the other hand, some others point to the great divergence beginning in the sixteenth $\mathrm{CE}$ and accelerating during the British colonial rule (Broadway et al., 2015). The subsequent steep decline of India's economy, over almost a four-century span, continues to reverberate to the India of the present day - in terms of discussions about the relative effects of exploitative British colonialism versus relative deficits and lags, during the early modern period, in political acumen and technological progress in India (and Asia) in comparison to Europe. Various papers in this special issue look into the impact of colonialism on different facets of markets, consumption and marketing.

Datta offers fascinating insights into the development of advertising in India with the analysis of Bengali commercial art in the late colonial period. She closely examines the autobiography of Ranen Ayon Dutt and some of his commercial art work. Datta reveals how the dynamics of modern liberal values - mediating through the colonial capitalist structure in relation to the regional particularities of Bengal - opened up a new space of cosmopolitanism. As a result, there was an attempt to reframe cultural practices in the light of a broader global history of interrogation, reason, change and emancipation.

Staying with the theme of Bengal and development of business in the region, Roy's account of the business activities of Dwarkanath Tagore help to understand how he used what is now known as an integrated marketing approach. Roy argues that much before the concept became fashionable, both in practice and theory, Tagore had mastered the art of it in the early nineteenth CE. Accordingly, Tagore built multiple business partnerships with the British East India Company and other enterprises in a myriad of businesses and used forward integration techniques - such as distribution, publishing, advertising and promotion - to market his products effectively. 
In another article that directly examines India's colonial encounter, Sreekumar looks into how British products were received by Indians. In a way, Sreekumar shows that some of the more recent debates about globalization, localization and glocalization are old issues that keep resurfacing under new labels in different eras. British products and consumption practices were contested by Indian consumers and intellectuals, as Sreekumar shows in his article. Sreekumar also focuses on how the social registers of caste, gender and religion shaped the cultural negotiation process. He further points to how these aspects of consumption were not only informed by but also shaped the politics of nationalism.

Two papers deal with the issue of cultural branding. The papers by Shah and Alladi provide accounts of two iconic brands in India and show that cultural branding was well understood by very different actors dealing with Indian consumers. In a detailed account of khadi (homespun cotton fabric), Shah delves into its political economy and explains how the significance of khadi changed from being a mere cloth to a product of self-sufficiency and national importance in India's freedom movement. Her work based on Gandhi's writings and various other secondary sources - analyzes the evolution of khadi in its historical, social and political context in colonial India. In another historical analysis of branding, Alladi analyses the cultural roots of Godrej Storwel, the iconic steel almirah found in nearly all middle-class homes. She mobilizes primary sources such as company circulars, catalogs, letters, oral history interviews and newspaper and television advertisements. These papers help to understand the issue of branding in two very divergent settings in the country.

Based on archival work in their two papers, Tumbe and his colleagues uncover some important facets of marketing. In the first paper, Tumbe and Ralli examine agricultural marketing boards, Godrej and Cipla, and describe four eras of marketing in the country. In an interesting analysis, they point to how marketing first formally appeared in the context of public and agricultural sectors in the 1930s and was later adopted by large businesses. They further observe that marketing before the 1970s was without professional marketing managers, which later changed after the opening of Indian Institute of Management in Calcutta and Ahmedabad. In the second paper, Tumbe and Krishnakumar describe the evolution of retailing since the mid-nineteenth century. They point to the significance of several environmental influences such as the role of the state, colonialism, cooperative stores and high-end department stores. Looking at the case of Big Bazaar, they point to the role of service innovation in terms of home delivery and recreation of the bazaar atmosphere because of the norms of gender and community.

Finally, in another interesting piece examining the origins of market research practice in India, Parameswaran and Parameswaran show that market research started in the 1950s. They point to how it was initiated by Burmah-Shell, and in the absence of any local agency, S.H. Benson (London) Ltd was selected to undertake the pioneering market research. Accordingly, this led to the birth of Indian Market Research Service. They point to several unique experiences specific to the Indian context that shaped market research practices.

Summing up, this special issue presents a wide range of topics that should be of interest to both scholars and practitioners of marketing. It shows that Amero/Eurocentric research that has labeled Indian markets and marketing as underdeveloped has failed to understand its uniqueness and complexity. In perusing the articles in this issue, the significance of India's colonial encounter becomes evident. While colonialism is of great significance and has left deep economic, cultural and psychological imprints on the region (Bagchi, 1976; Chatterjee, 1993; Nandy, 1989), it would be limiting to reduce India's long and varied history to just this period and its postcolonial experiences. Future inquiries on history of marketing 
need to go beyond India's colonial encounter and take up the challenge of presenting 10,3 multiple histories of marketing in the region.

\section{Rohit Varman}

Indian Institute of Management Calcutta, India, and

Nikhilesh Dholakia College of Business Administration, University of Rhode Island, Kingston, Rhode Island, USA

\section{References}

Bagchi, A.K. (1976), "De-industrialization in India in the nineteenth century: some theoretical implications", Journal of Development Studies, Vol. 12 No. 2, pp. 135-164.

Chatterjee, P. (1993), The Nation and Its Fragments: Colonial and Postcolonial Histories (Vol. 11), Princeton University Press, Princeton, NJ.

Nandy, A. (1989), Intimate Enemy, Oxford University Press, Oxford.

Pomeranz, K. (2000), The Great Divergence: China, Europe, and the Making of the Modern World Economy, Princeton University Press, Princeton, NJ.

\section{Further reading}

Broadberry, S., Custodis, J. and Gupta, B. (2015), "India and the great divergence: an Anglo-Indian comparison of GDP per capita, 1600-1871”, Explorations in Economic History, Vol. 55, pp. 58-75. 